Brit. F. vener. Dis. (1968), 44, 220.

\title{
CEPHALORIDINE TREATMENT OF GONORRHOEA IN THE FEMALE*
}

BY

\author{
DAVID G. MCLONE†, ANGELO T. SCOTTI $†$, DAN M. MACKEY§, \\ AND \\ JAMES F. HACKNEY $\|$ \\ Fulton County Health Department, Atlanta, Georgia
}

The emergence of strains of Neisseria gonorrhoeae relatively resistant to penicillin has created difficulties in the treatment of gonorrhoea (Thayer and Moore, 1964). Progressively larger doses of the drug are required for cure, and if the present trend continues, we may in the near future be faced with strains completely resistant to penicillin. The need to evaluate alternative drugs for treating this infection is therefore urgent. By preference the agent should be injectable and effective in a single dose; this procedure is more economical and convenient for both physician and patient and has the added advantage that the physician can be certain that the patient has received the amount prescribed.

A possible alternative drug which has broad antibacterial activity and can be given in a single intramuscular injection is cephaloridine (Apicella, Perkins, and Saslaw, 1966). To evaluate the efficacy of a single intramuscular injection of this drug, 85 female patients with positive cultures for Neisseria gonorrhoeae were treated and followed.

\section{Material and Methods}

The study group comprised 140 female patients ranging in age from 15 to 56 years who had attended a large metropolitan venereal disease clinic; 83 had attended spontaneously and 57 had been referred as sexual contacts of males with proven gonorrhoeal infection.

Cultures were obtained from the urethra, cervix, and rectum of each patient. The urethral specimens were obtained with a $3 \mathrm{~mm}$. platinum wire loop and the cervical and rectal specimens with a sterile cotton swab. Diagnosis was based on the growth of morphologically typical, Gram-negative, oxidase-positive diplococci on

*Received for publication March 4, 1968.

tSA Surgeon (R) (T), Venereal Disease Program, National Communicable Disease Center, Public Health Service, U.S. Department of Health, Education, and Welfare, assigned to the Fulton County Health Department, Atlanta, Georgia.

¥Assistant to the Chief, Venereal Disease Program, National Communicable Disease Center, Public Health Service, U.S. Department of Health. Education, and Welfare, Atlanta, Georgia.

$\S$ Assistant to the Chief, Venereal Disease Program, National Communicable Disease Center, Public Health Service, U.S. Department of Health, Education, and Welfare, Atlanta, Georgia.

II Director, Fulton County Health Department, Atlanta, Georgia.
(I)
Thayer-Martin selective medium (Thayer and Martin, 1966). Patients with a positive culture from any one of the three sites were treated with $2 \mathrm{~g}$. cephaloridine (Eli Lilly-Loridine) intramuscularly and were instructed to return to the clinic within 96 hours. From those who returned after treatment, cultures were again obtained from all three sites. The criterion for cure was the absence of growth from all sites.

\section{Results}

Of the 140 patients studied, only 85 (61 per cent.) had positive cultures from one or more sites (Table I). Only these patients were treated and 56 returned for follow-up examination. Eight (14 per cent.) of the 56 had positive cultures at their post-treatment visit and thus were considered to demonstrate treatment failure. Three of the eight who failed to respond to treatment did not make their posttreatment visit until more than 96 hours later and the chance of re-infection was thus proportionately greater.

TABLE I

INITIAL CULTURE RESULTS, BY SITE OF SPECIMEN, IN 85 INFECTED FEMALES

\begin{tabular}{|c|c|c|c|c|}
\hline \multicolumn{3}{|c|}{$\begin{array}{l}\text { Result of Culture and Site } \\
\text { of Specimen }\end{array}$} & \multicolumn{2}{|c|}{ Patients } \\
\hline Cervix & Urethra & Rectum & Number & Per cent. \\
\hline $\begin{array}{l}+ \\
+ \\
+ \\
+ \\
\pm \\
- \\
-\end{array}$ & $\begin{array}{l}\overline{-} \\
\overline{+} \\
\overline{+} \\
+ \\
\overline{+} \\
+\end{array}$ & $\begin{array}{l}- \\
\overline{+} \\
+ \\
+ \\
+ \\
+ \\
+\end{array}$ & $\begin{array}{r}14 \\
24 \\
14 \\
23 \\
4 \\
4 \\
2\end{array}$ & $\begin{array}{r}16 \cdot 5 \\
28 \cdot 2 \\
16 \cdot 5 \\
27 \cdot 1 \\
4 \cdot 7 \\
4 \cdot 7 \\
2 \cdot 4\end{array}$ \\
\hline Total + & Total + & Total + & $\begin{array}{l}75 \\
53 \\
43\end{array}$ & $\begin{array}{l}88 \cdot 2 \\
62 \cdot 4 \\
50 \cdot 6\end{array}$ \\
\hline \multicolumn{3}{|c|}{ Total + at One or More Sites } & 85 & $100 \cdot 0$ \\
\hline
\end{tabular}

The only treatment complication was one case of hypotension immediately after the injection; the patient recovered spontaneously within a few minutes and no specific treatment was necessary.

An analysis of culture results according to site cultured revealed that 63 ( 74 per cent.) had positive 
cultures from more than one site and 75 (88 per cent.) had positive cervical cultures. However, four ( 4.7 per cent.) had positive urethral cultures only and four others $(4 \cdot 7$ per cent.) had positive rectal cultures only.

\section{Discussion}

If the cervix only had originally been cultured, 12 per cent. (10 out of 85 ) of the cases would have been missed. Culturing the cervix and only one other site (urethra or rectum) would still have allowed almost 5 per cent. to have gone undetected.

Only 72 per cent. (41 of 57) of those women known to be sexual contacts of an infected male had positive cultures for gonorrhoea (Table II). One obvious explanation for this is that we failed to detect the infection in some or all of the remaining sixteen cases (28 per cent.). Another explanation is that not all women exposed to Neisseria gonorrhoeae become infected. A combination of these two factors can probably account for the discrepancy. Such factors as inaccurate histories, self-medication, and cleansing of the genital-rectal areas before the clinic visit may account for a small proportion of our group of "non-infected" contacts.

The finding of infection in 53 per cent. of patients who attended spontaneously is not surprising, since the clinic is a venereal disease clinic and most patients presenting themselves had some reason to suspect that they had become infected.

The pattern of positive results on follow-up cultures deserves comment. Five patients were still harbouring gonococci 48 to 96 hours after treatment (Table III). All had positive results to cervical cultures and at least one other site originally; however, on follow-up, two had negative cervical cultures but positive cultures from one of the other sites (Table IV).

TABLE IV

COMPARISON OF SPECIMEN SITES OF POSITIVE CULTURES BEFORE AND AFTER TREATMENT

\begin{tabular}{|c|c|c|c|c|}
\hline \multirow[b]{2}{*}{ Patient No. } & \multirow{2}{*}{$\begin{array}{l}\text { Culture in } \\
\text { Relation to } \\
\text { Treatment }\end{array}$} & \multicolumn{3}{|c|}{ Specimen Site } \\
\hline & & Cervix & Urethra & Rectum \\
\hline 1 & $\begin{array}{l}\text { Before } \\
\text { After }\end{array}$ & + & + & + \\
\hline 2 & $\begin{array}{l}\text { Before } \\
\text { After }\end{array}$ & + & \pm & $\overline{-}$ \\
\hline 3 & $\begin{array}{l}\text { Before } \\
\text { After }\end{array}$ & + & \pm & $\overline{+}$ \\
\hline 4 & $\begin{array}{l}\text { Before } \\
\text { After }\end{array}$ & \pm & + & $\overline{-}$ \\
\hline 5 & $\begin{array}{l}\text { Before } \\
\text { After }\end{array}$ & \pm & $z$ & + \\
\hline
\end{tabular}

TABLE II

COMPARISON OF RESULTS OF INITIAL CULTURES IN KNOWN CONTACTS AND SELF-REFERRED PATIENTS

\begin{tabular}{l|c|c|c|r|r|r}
\hline \multirow{2}{*}{ Classification } & \multicolumn{2}{|c|}{ Sexual Contacts } & \multicolumn{2}{|c|}{ Self-referred } & \multicolumn{2}{|c}{ Total } \\
\cline { 2 - 6 } & Number & Per cent. & Number & Per cent. & Number & Per cent. \\
\hline Total Examined & 57 & $100 \cdot 0$ & 83 & $100 \cdot 0$ & 140 & $100 \cdot 0$ \\
Total Infected & 41 & $71 \cdot 9$ & 44 & $53 \cdot 0$ & 85 & $60 \cdot 7$ \\
\hline Positive Cervical Culture & 39 & $95 \cdot 1$ & 36 & $81 \cdot 8$ & 75 & $88 \cdot 2$ \\
\hline
\end{tabular}

TABLE III

RESULTS OF TREATMENT OF INFECTED PATIENTS

\begin{tabular}{|c|c|c|c|c|c|c|}
\hline \multirow{2}{*}{ Results of Treatment } & \multicolumn{2}{|c|}{ Sexual Contacts } & \multicolumn{2}{|c|}{ Self-referred } & \multicolumn{2}{|c|}{ Total } \\
\hline & Number & Per cent. & Number & Per cent. & Number & Per cent. \\
\hline Total Patients Treated & 41 & $100 \cdot 0$ & 44 & $100 \cdot 0$ & 85 & $100 \cdot 0$ \\
\hline Patients Returning & 32 & $78 \cdot 0$ & 24 & $54 \cdot 5$ & 56 & $65 \cdot 9$ \\
\hline Negative Culture & 26 & $81 \cdot 3$ & 22 & $91 \cdot 7$ & 48 & $85 \cdot 7$ \\
\hline 48-96 hrs & 5 & $15 \cdot 6$ & 0 & $0 \cdot 0$ & 5 & $8 \cdot 9$ \\
\hline Positive Culture: after $96 \mathrm{hrs}$ * & 1 & $3 \cdot 1$ & 2 & $8 \cdot 3$ & 3 & $5 \cdot 4$ \\
\hline
\end{tabular}

*All after 10 days. 
In this group 82 per cent. of the infected women had positive results to cervical cultures, compared with 95 per cent. of the contacts of male cases of gonorrhoea; this difference was not statistically significant. It is, therefore, important to re-culture all sites at the follow-up examination. It is tempting to re-culture only the cervix, but if we had done so two of our eight treatment failures (one-fourth) would have been regarded as cures. The most satisfactory procedure for follow-up would be to re-culture all three sites.

In one patient (Case 3 ) in which the cervical culture was positive initially and at follow-up, the culture results from the other sites were surprising; the urethral culture which was positive originally had become negative, but the rectal culture which was negative originally had become positive. Possible explanations for this might be rectal selfcontamination, poor technique in performing the cultures, or an error in recording or labelling.

Of those considered to be treatment failures only five returned for post-treatment examination within the prescribed 96 hours. Three patients considered to be treatment failures did not return until more than 10 days after treatment and in such cases the chance of re-infection is much greater. There is no reason to expect a higher failure rate among those who did not return for follow-up than in those who did. One may then conclude that the treatment schedule used in this study was effective in at least 85 per cent. of cases and in 90 per cent. if probable re-infections are excluded.
Summary

The results presented here indicate that a single intramuscular injection of $2 \mathrm{~g}$. cephaloridine is adequate treatment for uncomplicated gonorrhoea in the female. Although the cure rate obtained here is not as good as might be hoped for, it is at least as good as that obtained with other recommended treatment schedules (Lucas, Price, Thayer, and Schroeter, 1967).

\section{REFERENCES}

Apicella, M. A., Perkins, R. L., and Saslaw, S. (1966). Amer.F. med. Sci., 251, 266.

Lucas, J. B., Price, E. V., Thayer, J. D., and Schroeter, A. (1967). New Engl. F. Med., 276, 1454.

Thayer, J. D., and Martin, J. E. (1966). Publ. Hlth Rep. (Wash.), 81, 559.

- and Moore, M. B. (1964). Med. Clin. N. Amer., 48, 755.

\section{Le traitement de la blennorragie chez la femme par la céphaloridine RÉSUMÉ}

Les résultats présentés ici indiquent qu'une seule injection intramusculaire de $2 \mathrm{~g}$. de céphaloridine est un traitement adéquat de la blennorragie sans complications chez la femme. Malgré que le taux de cure ne soit pas aussi bon que l'on pourrait espérer, il est au moins aussi bon que celui obtenu par les autres posologies recommandés (Lucas et alia, 1967). 